Supplement of Biogeosciences, 18, 1269-1289, 2021 https://doi.org/10.5194/bg-18-1269-2021-supplement (C) Author(s) 2021. This work is distributed under the Creative Commons Attribution 4.0 License.

(c) (1)

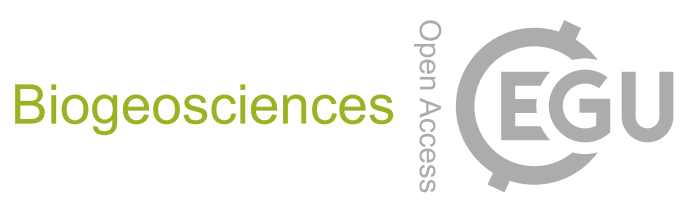

Supplement of

\title{
Reviews and syntheses: The biogeochemical cycle of silicon in the modern ocean
}

\section{Paul J. Tréguer et al.}

Correspondence to: Paul Tréguer (paul.treguer@univ-brest.fr) and Jill Sutton (jill.sutton@univ-brest.fr)

The copyright of individual parts of the supplement might differ from the CC BY 4.0 License. 


\section{SUPPLEMENTAL INFORMATION}

This document complements the review article. It provides detailed legends for Figures 1, 2 and 4, and a few additional comments to the main text. Annex 1 shows data for the determination of biogenic silica $(\mathrm{bSi})$ production measured by isotopic techniques.

\section{Section 1. Introduction}

\section{Detailed legend of Fig. 1 and flux abbreviations}

Schematic view of the Si cycle in the modern world ocean (input, output, and biological $\mathrm{Si}$ fluxes), and possible balance (total $\mathrm{Si}$ inputs $=$ total $\mathrm{Si}$ outputs $=15.6 \mathrm{Tmol}-\mathrm{Si}_{\mathrm{yr}}{ }^{-1}$ ) that is in reasonable agreement with the individual range of each flux (F), see Tables 1 and 2. All fluxes are in Tmol-Si $\mathrm{yr}^{-1}$.

-Inputs: Rivers: $\mathrm{F}_{\mathrm{R}(\mathrm{dSi}+\mathrm{aSi})}=8.1$; Aeolian inputs: $\mathrm{F}_{\mathrm{A}}=0.5$; Glacial meltwater: $\mathrm{F}_{\mathrm{ISMW}}=0.3$; Submarine groundwater: $\mathrm{F}_{\mathrm{GW}}=3.1$; Dissolution of minerals: $\mathrm{F}_{\mathrm{W}}=1.9$; Hydrothermal: $\mathrm{F}_{\mathrm{H}}=$ 1.7

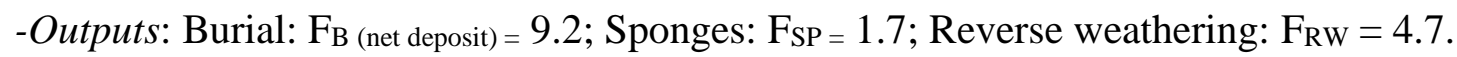

-Biological and other fluxes: Uptake (pelagic production) $=\mathrm{F}_{\mathrm{P}(\text { gross })}=255$; Recycling (surface) $\mathrm{F}_{\mathrm{D}(\text { surface })}=143$ (D: $\mathrm{P}=0.56$ according to Tréguer and De La Rocha 2013); Export: $\mathrm{F}_{\mathrm{E}}=112$; Recycling (deep) $\mathrm{F}_{\mathrm{D}(\text { deep })}=28\left(\mathrm{~F}_{\mathrm{D}(\text { deep })} / \mathrm{F}_{\mathrm{E}}=0.25\right.$ according to Tréguer and De La Rocha 2013); Rain $=\mathrm{F}_{\mathrm{S}(\text { rain })}=84.0$; Recycling (sediment-water interface) $\mathrm{F}_{\mathrm{D}(\text { benthic })}=74.8$; upwelling, diffusion: $F_{\text {upw/ed }}=102.8$.

Flux abbreviations: dSi input fluxes: $\mathrm{F}_{\mathrm{R}}$ total river net discharge, $\mathrm{F}_{\mathrm{A}}$ dissolution of aeolian transported siliceous dusts, $\mathrm{F}_{\mathrm{GW}}$ submarine groundwater discharge, $\mathrm{F}_{\mathrm{W}}$ dissolution of siliceous material transported from land on the continental margins, and of basalt, $\mathrm{F}_{\mathrm{H}}$ hydrothermal activity of the oceanic ridges (axis + off axis), FISMw ice shelf melt water flux (subglacial melt water + basal melting of ice shelves + melting of icebergs).

Si output fluxes: $\mathrm{F}_{\mathrm{B}(\mathrm{net} \text { deposit) }}$ long-term burial of biogenic silica, $\mathrm{F}_{\mathrm{SP}}$ siliceous sponges, $\mathrm{F}_{\mathrm{RW}}$ reverse weathering by formation of authigenic silicate minerals.

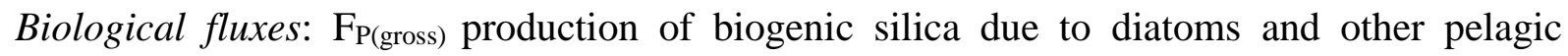
silicifiers, $F_{E(e x p o r t)}$ export flux of biogenic silica to the deep reservoir, $F_{S(r a i n)}$ part of the export flux that reaches the sediment - water interface, $\mathrm{F}_{\mathrm{B} \text { (net deposit) }}$ long-term accumulation of biogenic opal in coastal and abyssal, sediments. 
Note that the dSi uptake due to benthic organisms is not represented on Fig. 1. Indeed, the total $\mathrm{bSi}$ production of benthic diatoms is presently unknown but it should be $<5$ Tmol-Si $\mathrm{yr}^{-1}$ (Leynaert et al., work in progress), and that the total bSi production of sponges $(6.1( \pm 5.9)$ Tmol-Si $\mathrm{yr}^{-1}$ ) is still preliminary (Maldonado et al., work in progress).

Other fluxes: $\mathrm{F}_{\mathrm{D} \text { (surface) }}$ recycling of $\mathrm{Si}$ by dissolution of the biogenic silica in the surface reservoir, $\mathrm{F}_{\mathrm{D}(\mathrm{deep})}$ part of the export flux that dissolves in the deep reservoir, $\mathrm{F}_{\mathrm{upw} / \mathrm{ed}}$ transfer of

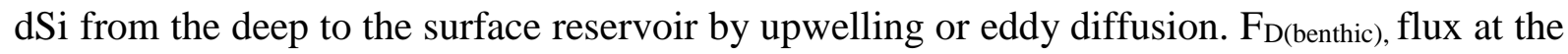
sediment - water interface, is according to Tréguer and De La Rocha 2013).

\section{Section 2 -The input fluxes}

\subsection{Detailed legend of Figure 2.}

Schematic view of the low temperature processes that control the dissolution of (either amorphous or crystallized) siliceous minerals in seawater in the coastal zone and in the deep ocean, feeding $\mathrm{F}_{\mathrm{GW}}$ and $\mathrm{F}_{\mathrm{W}}$. These processes (white arrows) correspond to low or medium energy flux dissipated per volume of a given siliceous particle in the coastal zone, in the continental margins, and in the abysses, and to high kinetic energy flux dissipated in the surf zone. Inputs of siliceous biogenic and lithogenic silica into the ocean are mainly due to suspended matter transferred from the continent. Rivers support the main transfer of Si to the coastal zone, either as $\mathrm{dSi}$ or as aSi. Abundant transfer of siliceous suspended matter into the ocean is also expected from river mouths and deltas through dissemination of suspended matter in the coastal zone, in the continental margin, and beyond to the abysses. In sandy and permeable soil zones dSi is also transferred from the continent to the coastal zone through submarine groundwater discharge processes either as net fresh water inputs or as brackish/seawater recycling due to tidal pumping. In the surf zone, low temperature dissolution of grains of lithogenic silica (quartz, feldspar, etc.) could be intense under the pressure of the intensive and continuous shaking due to waves. For the sake of clarity, we distinguish the processes at work in a quiet zone that receive river inputs from those occurring in a sand beach zone subject to strong dissipation of energy due to wave motion. Note that neither the lowtemperature dissolution of wind-borne siliceous material $\left(\mathrm{F}_{\mathrm{A}}\right)$ nor that occurring in hightemperature hydrothermal systems $\left(\mathrm{F}_{\mathrm{H}}\right)$ are represented on this figure.

\subsection{Dissolution of minerals}

Regarding the marine component of $F_{W}$ dissolution of minerals, Fabre et al. (2019) (main text reference list), focused on wave and tidal action prevailing in the intertidal surf zone (Fig. 2). From laboratory experiment with pure quartz, they showed that quartz grains submitted to 
violent agitation are capable of substantial dissolution of silica at time scale of days. According to these authors, the flux of dissolution of siliceous material from sandy beaches is $\mathrm{F}_{\text {dissolution }}=$ $\mathrm{k}\left(\mathrm{T}^{\circ} \mathrm{C}\right) \times \mathrm{S}_{\text {reactive }} \times\left(\mathrm{C}^{*}-\mathrm{C}_{\mathrm{sw}}\right)$. It corresponds to a net input of $\mathrm{dSi}$ to the ocean. In this equation, $\mathrm{k}\left(\mathrm{f}\left(\mathrm{T}^{\circ} \mathrm{C}\right)\right)$ in $\mathrm{m} \mathrm{s}^{-1}$ is the mass transfer coefficient, Sreactive in $\mathrm{m}$ is the reactive surface of sand grains, $\mathrm{C}^{*}$ in mol-Si $\mathrm{L}^{-1}$ is the temperature-dependent solubility limit of sand at thermodynamic equilibrium, and $\mathrm{C}_{\mathrm{sw}}$, in mol-Si $\mathrm{L}^{-1}$ is the coastal seawater silicic acid concentration. Assuming that all sandy beaches is composed of quartz, Fabre et al. (2019) calculated a global flux of 3.2 $( \pm 1.0) \mathrm{Tmol} \mathrm{Si} \mathrm{yr}^{-1}$. However, this estimate is not well constrained.

Firstly, it is clear that the mineral composition of the world ocean beaches is not entirely composed of quartz. Indeed, the composition of sandy beaches is variable and represent $31 \%$ of the coastline of the continents at world scale (Luijendijk et al, 2018, main text reference list). Sandy beaches are composed both of non-siliceous materials (mostly calcareous), and diverse siliceous types of materials (amorphous silica, quartz, feldspars, clays, etc.). These siliceous materials have different solubility and dissolution rates in seawater (S1: Lerman et al., 1975; S2: Hurd et al., 1979), and they can be more or less coated by organic and metals, which affect silica dissolution (e.g. S3: Loucaides et al. 2010; S4: Wiley, 1975). These differing sand compositions directly affects the value of $\mathrm{S}_{\text {reactive }}$ as well as that of $\mathrm{C}^{*}$.

Secondly, in surf zones the mixing conditions of sand and seawater can be very variable, both over time and at local and regional scale, thus affecting the solid to liquid phase ratio, and the values of the $\mathrm{C}^{*}$.

Thirdly, Fabre et al (2019)'s value for $\mathrm{C}_{\mathrm{sw}}$ (i.e. $85.4 \mu \mathrm{M}$ ), is far too high for coastal waters, irrespective of its regional context in the world ocean.

Finally, $\mathrm{C}_{\mathrm{sw}}$ can be seasonally variable, particularly in temperate zones.

Also note that, by definition, this flux is already included in the marine SGD estimate according to Cho et al. (2018) (main text reference list)

\section{REFERENCES:}

S1. Lerman, A., Mackenzie F.T., Bricker, O.P. Rates of dissolution of aluminosilicates in seawater, EPSL, 25: 8288.

S2. Hurd, D.C., Fraley, C., Fugate J.K. Silica apparent solubilities and rates of dissolution and precipitation (1979) DOI: 10.1021/bk-1979-0093.ch021

S3. Loucaides et al. Seawater-mediated interactions between diatomaceous silica and terrigenous sediments: Results from long-term incubation experiments, Mar. Chem., 3, 241-251.

S4. Wiley, J.D. Rates of dissolution of aluminosilicates in seawater. Mar. Chem., 3, 241-251.

\section{Section 3 -The output fluxes}




\section{Deposition of sponge silica in marine sediments}

The annual rate of sponge silica deposition to the sediments, unlike in diatoms, cannot be easily calculated from annual production rates. The longevity of sponges, which ranges from months or years to even centuries or millennia (S5: Elwood et al., 2007; S6: Mcmurray et al., 2008; Jochum et al. 2017, see main text reference list), decouples the process of skeleton production — which slowly accumulates bSi over the sponge lifespan - from the process of releasing the accumulated bSi into the sediments — which occurs within weeks to months after sponge death. The deposition of sponge bSi is also decoupled from the rain of planktonic, and therefore, from the rate of sediment deposition. The reason of this is in the benthic nature of sponges. Sponges live already attached to the bottom, so their bSi does no transit through the water column once sponges die. While the organic components of the body become rapidly degraded (S7: Rützler and Mcintyre 1978), the mineral components (i.e. the siliceous skeletal pieces of sponges, called spicules) do not. The skeletal pieces fall directly on the seafloor at the site where the sponge was growing, forming a spicule patch (S8: Laguionie-Marchais et al., 2015), which can in some cases persist for a long time (S9: Bett and Rice, 1992), being slowly disaggregated by the action of scavengers and other benthic macrofauna (S10: Katz et al., 2016), also by the action of bottom currents, turbidity currents included.

Once the spicules are delivered to the bottom, the period of time needed for them to be buried and become accumulated bSi will mostly depend on the local rates of sediment deposition, though also on the intensity of bioturbation (S10: Katz et al., 2016). In a study that has considered sediments from a variety of marine environments ranging from shallow bays to abyssal bottoms, the time required for the sponge spicules to reach the condition of permanently buried bSi ranged from 471 to 74,074 years, depending on the depositional nature of the local bottom (S11: Maldonado et al., 2019).

\section{REFERENCES:}

S5. Ellwood, M. J., M. Kelly, and B. Richer De Forges. Silica banding in the deep-sea lithistid sponge Corallistes undulatus: Investigating the potential influence of diet and environment on growth. Limnol. Oceanogr. 52: 1865-1873 (2007).

S6. Mcmurray, S. E., J. E. Blum, and J. R. Pawlik. Redwood of the reef: growth and age of the giant barrel sponge Xestospongia muta in the Florida Keys. Mar. Biol. 155: 159-171 (2008).

S7. Rützler, K. and Macintyre, I. G. Siliceous sponge spicules in coral reefs sediments. Marine Biology, 49 (2), 147-159 (1978).

S8. Laguionie-Marchais C., Kuhnz L. A., Huffard C. L., Ruhl H. A., Smith K. L., Jr., Spatial and temporal variation in sponge spicule patches at Station M, northeast Pacific. Mar. Biol. 162, 617-624 (2015). 
S9. Bett, B. J., and Rice, A. L. The influence of hexactinellid sponge (Pheronema carpenteri) spicules on the patchy distribution of macrobenthos in the Porcupine Seabight (bathyal NE Atlantic). Ophelia, 36, 217226 (1992).

S10. Katz, T., Yahel, G., Tunnicliffe, V., Herut, B., Whitney, F., Snelgrove, P. V. R., \& Lazar, B. (2016). The silica cycle in a Northeast Pacific fjord; the role of biological resuspension. Progr. Oceanogr. 147, 20-21 (2016).

S11. Maldonado, M., López-Acosta, M., Sitjà, C., García-Puig, M., Galobart, C., Ercilla, G., \& Leynaert, A. Sponge skeletons as an important sink of silicon in the global oceans. Nature Geoscience, 12 (10), 815822 (2019).

\section{Section 4 -The biological fluxes}

\subsection{Biogenic silica production as measured by isotopic techniques}

Annex 1 shows all bSi production data with corresponding references.

\section{2 bSi pelagic production uncertainties}

The bSi pelagic production estimates from satellite NPP products, ocean biogeochemical models, and empirical studies each have their own uncertainty. When NPP is extrapolated to silica production, values are multiplied by estimates of the fraction of primary productivity done by diatoms and then a $\mathrm{Si}: \mathrm{C}$ ratio. Of these, the choice of a $\mathrm{Si}: \mathrm{C}$ ratio for the HNLC regions is the most uncertain. Our chosen value of 0.52 is 4 fold higher than for nutrient-replete temperate diatoms (Brzezinski, 1985, see main text reference list), but field observations suggest anywhere from no effect to an 8-fold increase (S12: Marchetti \& Harrison, 2007, S13 : Timmermans et al., 2004). Biases in satellite NPP models also contribute to uncertainties in estimates of Si production. Particularly relevant are potential biases in Southern Ocean chlorophyll concentrations (and consequently, NPP), which may be underestimated in the Southern Ocean by as much as a factor of 3-4 (S14: Johnson et al., 2013).

For the biogeochemical models the two main sources of uncertainty are the extrapolation from silica export to gross silica production using D:P ratios (Table 1 of Tréguer \& De La Rocha, 2013, main text reference list), as well as uncertainties in the parametrization of Southern Ocean physics and biology. For the seven GOBMs that report separate estimates of net silica production for the Southern Ocean, when Southern Ocean silica production is regressed against total global silica production the fitted line has an $\mathrm{R}^{2}$ value of 0.96 with a slope equal to 1.05 $( \pm 0.11)$. This points to model parameterizations of Southern Ocean physics and/or biology as the major determinant of differences in global silica production estimates among GOBMs. For the global bSi pelagic production estimates derived from field data, extrapolation over both time and space is required. Few empirical studies of bSi production over an entire year are 
available. The vast majority of annual estimates determined for Longhurst provinces are extrapolated from field programs lasting a few weeks or less. Data sparsity remains a problem, and in the analysis presented here some Longhurst zones contain only a single measurement and nearly half of zones have no data at all (main text Fig. 3).

\section{REFERENCES}

S12. Marchetti, A., Harrison, P.J. Coupled changes in the cell morphology and elemental (C, N, and Si) composition of the pennate diatom Pseudo-nitzschia due to iron deficiency. Limnol. Oceanogr. 52, 22702284 (2007).

S13. Timmermans, K.R., van der Wagt, B., de Baar, H.J.W. Growth rates, half-saturation constants, and silicate, nitrate, and phosphate depletion in relation to iron availability of four large, open-ocean diatoms from the Southern Ocean. Limnol. Oceanogr. 49, 2141-2151 (2004).

S14. Johnson, R., Strutton, P.G., Wright, S.W., McMinn, A., Meiners, K.M. Three improved satellite chlorophyll algorithms for the Southern Ocean. J. Geophys. Res. Ocean. 118, 3694-3703 (2013).

\section{3 bSi production: contribution of benthic diatoms}

Determination of bSi production by microphytobenthos is still in its infancy. However, we can already foresee its potential impact in two ways. Through intensive studies in a temperate subtidal ecosystem (S15: Ni Longphuirt et al. 2009, S16 : Leynaert et al. 2009, and S17 : Chatterjee et al., 2013) we conservatively estimate that benthic diatoms can produce 1 mol-Si $\mathrm{m}^{-2} \mathrm{yr}^{-1}$. Extrapolation to the photic area of the world coastal ocean gives $6.8 \mathrm{Tmol}-\mathrm{Si}_{\mathrm{yr}}{ }^{-1}$. Cahoon (1999) (S18) proposed a global estimate of annual benthic microalgal primary

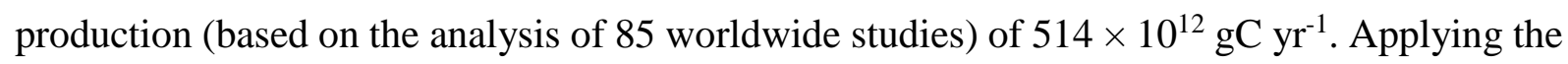
Brzezinski (1985) (main text reference list) mean Si/C molar ratio for marine diatom of 0.13 to

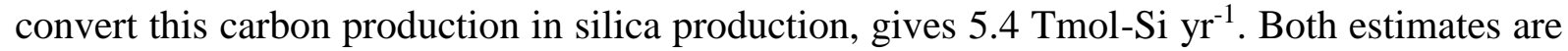
in good agreement. Therefore, the biogenic silica production by the microphytobenthos might represent about $2.5 \%$ of the global bSi production. It remains to be determined what proportion of this flux will finally contributes to the net sink of bSi. Preliminary studies have shown that $\mathrm{bSi}$ dissolution rates of benthic diatoms are 10 times slower than pelagic diatoms measured in the same conditions.

\section{REFERENCES}

S15. Ni Longphuirt, S. et al. Diurnal heterogeneity in silicic acid fluxes in shallow coastal sites: causes and implications. Estuar. Coast. Shelf Sci. 82, 495-502 (2009).

S16. Leynaert, A., Longphuirt, S. N., Claquin, P., Chauvaud, L. \& Ragueneau, O. No limit? The multiphasic uptake of silicic acid by benthic diatoms. Limnol. Oceanogr. 54, 571-576 (2009).

S17. Chatterjee, A. et al. Comparative dynamics of pelagic and benthic micro-algae in a coastal ecosystem. Estuarine, Coastal and Shelf Science 133, 67-77 (2013). 
S18. Cahoon, L. B. The role of benthic microalgae in neritic ecosystems. in Oceanography and Marine Biology. An Annual Review. vol. 37, CRC Press (1999).

\section{Section 5 - Discussion}

5.1 Introduction to Fig. 4: Depiction of a schematic Si cycle in the coastal and continental margin zone (CCMZ), excluding coastal upwelling, linked to the rest of the world ocean (« open ocean » zone including upwelling and polar zones). In principle, the CCMZ comprises proximal and distal coastal zones, as defined by Laruelle et al. (2009) (see main text reference list), which includes coastal upwelling in the distal coastal zone. However, in coastal upwelling zones both physical and biogeochemical dynamics are markedly different from those in the CCMZ as represented by Jeandel et al. 2016 (see main text reference list). Indeed, if in the CCMZ the transfer of material from land to ocean plays a major role in physical and biogeochemical processes, in coastal upwelling zones the bSi production is mainly fueled by dSi flux from below (i.e. from deeper in the water column), as it does for the global ocean sensu lato (Fig. 1). Therefore, in our synthesis quantifying the Si cycle in the «boundary exchange » zone, coastal upwelling is discarded from the CCMZ and conceptually incorporated to the «open ocean » zone, as shown in Fig. 4. This figure represents a possible Si cycle assuming steady state in the CCMZ and in the rest of the world ocean (so called « open ocean »), that is with total inputs = total outputs $=15.6$ Tmol-Si $\mathrm{yr}^{-1}$.

\subsection{Detailed legend of Fig. 4}

Input and dSi fluxes (grey arrows), outputs and biological fluxes (black arrows). In this steadystate scenario total inputs $=$ total outputs $=15.6 \mathrm{Tmol}_{-} \mathrm{Si}_{\mathrm{yr}}{ }^{-1}$ (consistent with main text Figure 1). Note that (1) in the CCMZ the burial flux of bSi (3.7 $\left.\mathrm{Tmol}_{-} \mathrm{Si}_{\mathrm{yr}}^{-1}\right)$ and the reverse weathering flux (4.7 Tmol-Si $\mathrm{rr}^{-1}$ ) (authigenic siliceous material) are fed by the export flux of biogenic silica, and (2) the « open ocean » deficiency in dSi (4.7 $\left.\mathrm{Tmol}^{-\mathrm{Si}_{\mathrm{yr}}}{ }^{-1}\right)$ is made up by a transfer from the CCMZ. For details about those inputs and outputs refer to the «inputs » and « outputs» sections of the main text. For abbreviations, see detailed legend of Fig. 1 in Supplement (section 1).

Additional comments of Figure 4:

-Estimates of burial rate (planktonic bSi): in the CCMZ (excluding coastal upwelling),

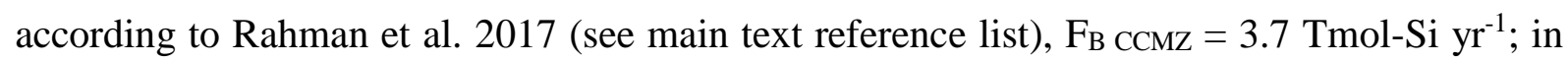
the « open ocean » zone, consistent with Fig. $1, \mathrm{~F}_{\mathrm{B} \text { openocean }}=9.2-3.7=5.5 \mathrm{Tmol}_{-\mathrm{Si} \mathrm{yr}}{ }^{-1}$. 
-Estimates of reverse weathering flux: in Fig. 4 CCMZ FRwCCMZ equals 4.7 Tmol-Si yr ${ }^{-1}$, (Rahman et al. 2017, see main text reference list). Reverse weathering in the «open ocean » remains unquantified.

-Following Annex 1, bSi production in the CCMZ* is $13 \%$ of the total production (255 Tmol-

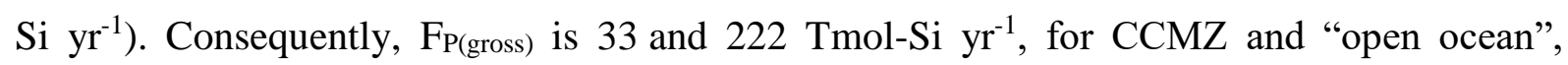
respectively.

-According to Tréguer and De La Rocha (2013) (see main text reference list), the pelagic production to dissolution ratio (D:P) being 0.51 and 0.57 , for CCMZ and "open ocean",

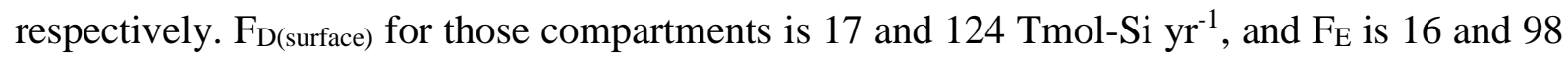
Tmol-Si $\mathrm{yr}^{-1}$, for CCMZ and "open ocean", respectively.

Note than every component of the inputs, outputs, and biological Si fluxes, although interacting between each other, is determined by independent methods, that is there is no overlap in the counting of these fluxes. Therefore, the export production (16.0 $\left.\mathrm{Tmol}_{-} \mathrm{Si}_{\mathrm{yr}}^{-1}\right)$ in particular feeds both the Si burial rate (3.7 Tmol-Si $\mathrm{yr}^{-1}$ ) and the reverse weathering flux (4.7 Tmol-Si $\mathrm{yr}^{-1}$ ). Figure 4 also shows that the "open ocean" bSi production is mostly fueled by dSi inputs from

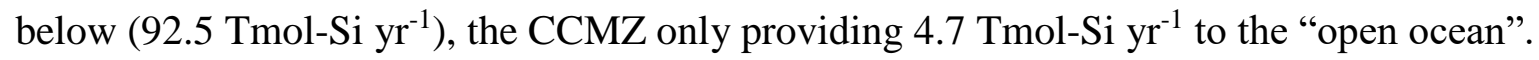
*Although specific estuarine sites have been studied (e.g. S19 DeMaster 1983, S20, Raimonet al. 2013), no global estimate is presently available for the estuarine bSi production. Given that most of estuarine waters are turbid we anticipate that the contribution of estuaries to the total $\mathrm{bSi}$ of the coastal zone should be small.

\section{REFERENCES}

S19. DeMaster D.J., Knapp, G.B., Nittrouer, C.A. Biological uptake and accumulation of silica on the Amazon continental shelf. Geochim. Cosmochim. Acta. 47, 1713-23 (1983).

S20. Raimonet M. et al. Spatio-temporal variability in benthic silica cycling in two macrotidal estuaries: Causes and consequences for local to global studies. Est. Coast. Shelf Sci., 119, 31-43 (2013a).

.

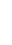




\begin{tabular}{|c|c|c|c|c|c|c|c|c|c|c|c|c|c|}
\hline \\
\hline \multirow{2}{*}{\begin{tabular}{|l|} 
Ail udiome \\
\end{tabular}} & Ocean & $\begin{array}{l}\text { Province } \\
\end{array}$ & System & sampling period & range $\mathrm{\rho bSi}$ & moyenne & longitude & \begin{tabular}{l|l} 
latitude \\
\end{tabular} & prod. duration & annual PBSi & annual PBSi & References & References \\
\hline & & & & & $\underset{\text { day }^{-1}}{\mathrm{mmol}^{-1} \mathrm{~m}^{-2}}$ & $\begin{array}{c}\mathrm{mmol}^{-S i} \mathrm{~m}^{-2} \\
\mathrm{day}^{-1}\end{array}$ & & & d & $\begin{array}{c}\mathrm{mmol} \mathrm{m}-^{2} \text { an } \\
1\end{array}$ & $10^{9} \mathrm{~mol} \mathrm{an}^{-1}$ & & \# \\
\hline Coastal & Pacific & ALSK & Bering Sea coastal & May/July 1979 - 1980 & 7-51 & 20,9 & -163 & 57 & 159 & 3317 & 1957 & Banahan and Goering, 1986 & 21 \\
\hline Polar & Southern Ocean & $\operatorname{cCSZ}$ & Ross Sea & jan/feb 1990 & & 34,0 & -175 & $-76,5$ & 79 & 2698 & & Nelson et al., 1991 & 22 \\
\hline Polar & Southern Ocean & $\operatorname{ccsz}$ & Pacific, Ross Sea & & 7,1-93 & 38,0 & 166 & -75 & 79 & 3015 & $6030 \mathrm{I}$ & Nelson and Smith, 1986 & 23 \\
\hline Polar & Southern Ocean & $\operatorname{ccsz}$ & Indian sector & spring 95/summer 95 & & 5,3 & 62 & -66 & 79 & 421 & & Caubert 1998 & 24 \\
\hline Polar & Southern Ocean & $\operatorname{ccsz}$ & Indian sector & & & 57,6 & 140,42 & $-66,42$ & 79 & 4570 & $9141 \mathrm{E}$ & I Beucher et al, 2004 & 25 \\
\hline Polar & Southern Ocean & PFZ & Weddell Scotia & 1992 & $19,6-60,7$ & 27,6 & -6 & $-49,5$ & 130 & 3582 & $32237 \mathrm{C}-2 \mathrm{l}$ & Quéguiner et al., 2002 & 26 \\
\hline Polar & Southern Ocean & PFZ & Weddell sea (EPOS 2) & 1988/1989 & $11,2-20,6$ & 15,9 & -49 & -57 & 130 & 2063 & $18571 \mathrm{C}$ & Quéguiner et al., 1991 & 27 \\
\hline Polar & Southern Ocean & PFZ & Indian sector & spring 95/summer 94 & $1,7-2,2$ & 2,0 & 62 & -50 & 130 & 260 & 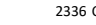 & Caubert 1998 & 24 \\
\hline Polar & Southern Ocean & POOZ & Pacific & oct/nov 97 & & 12,2 & -170 & -58 & 114 & 1385 & $16625 \mathrm{E}$ & Brzezinski et al, 2001 & 28 \\
\hline Polar & Southern Ocean & POOZ & Pacific & $\operatorname{dec} 97$ & & 27,1 & -170 & -60 & 114 & 3077 & $36928 \mathrm{E}$ & 3 Brzezinski et al, 2001 & 28 \\
\hline Polar & Southern Ocean & POOZ & East of New Zealand & & & 3,6 & -175 & -61 & 114 & 404 & $4851 \mathrm{I}$ & Nelson and Gordon, 1982 & 29 \\
\hline Polar & Southern Ocean & POOZ & Weddell Scotia & 1992 & & 3,5 & -6 & -52 & 114 & 397 & & Quéguiner et al., 2002 & 26 \\
\hline Polar & Southern Ocean & POOZ & Pacific & summer 1998 & $0,6-2,58$ & 2,6 & 142 & -52 & 114 & 293 & & Queguiner et al, 2001 & 30 \\
\hline Polar & Southern Ocean & POOZ & Kerguelen KEOPS 2 & 2011 & 3,09 - 47,9 & 23,2 & 72 & $-48,5$ & 114 & 2634 & $31614 \mathrm{C}$ & Closset et al 2014 & 31 \\
\hline Polar & Southern Ocean & POOZ & Indian sector & spring 95/summer 94 & $2,3-3,9$ & 3,1 & 62 & -54 & 114 & 352 & $4224 \mathrm{C}>2>2$ & Caubert 1998 & 24 \\
\hline Polar & Southern Ocean & POOZ & Indian sector & & & 10,2 & 142 & -55 & 114 & 1158 & 13899 & Beucher et al, 2004 & 25 \\
\hline Polar & Southern Ocean & $\mathrm{SIZ}$ & Weddell Sea & 1990 & $1,97-3,18$ & 2,6 & -40 & -70 & 114 & 294 & $6176 \mathrm{~L}$ & 5 Leynaert et al., 1993 & 32 \\
\hline Polar & Southern Ocean & $S \mid z$ & Pacific & janv-98 & & 22,6 & - 170 & -61 & 114 & 2566 & $53893 \mathrm{E}$ & B Brzezinski et al, 2001 & 28 \\
\hline Polar & Southern Ocean & $\mathrm{SIZ}$ & Pacific & feb march 98 & & 5,5 & -170 & -62 & 114 & 625 & 13116 & Brzezinski et al, 2001 & 28 \\
\hline Polar & Southern Ocean & SIZ & East of New Zealand & & & 6,8 & -175 & -64 & 114 & 768 & $16120 \mathrm{I}$ & Nelson and Gordon, 1982 & 29 \\
\hline Polar & Southern Ocean & $\mathrm{SIZ}$ & Weddell Sea (EPOS 2) & 1988/1989 & $2,3-22,9$ & 10,1 & -49 & -60 & 114 & 1147 & 24085 & Tréguer et al, 1991 & 33 \\
\hline Polar & Southern Ocean & $\mathrm{SIZ}$ & Weddell Scotia & 1992 & & 4,4 & -6 & -57 & 114 & 500 & $10493 \mathrm{C}$ & Quéguiner et al., 2002 & 26 \\
\hline Polar & Southern Ocean & 512 & Weddell sea (EPOS 2) & 1988/1989 & $6,0-20,0$ & 10,8 & -49 & $-60,5$ & 114 & 1226 & $25754 \mathrm{C} C 2>0$ & Quéguiner et al., 1991 & 27 \\
\hline Polar & Southern Ocean & $S \mid z$ & Indian sector & spring 95/sum. 94 & $5,7-8,9$ & 7,0 & 62 & $-58,5$ & 114 & 795 & $16693 \mathrm{C}>>2 \mathrm{C}$ & 3 Caubert 1998 & 24 \\
\hline Polar & Southern Ocean & SIZ & Indian sector & & & 7,9 & 138,68 & -65 & 114 & 897 & $18839 \mathrm{E}$ & Beucher et al, 2004 & 25 \\
\hline Polar & Southern Ocean & SUBANT & Indian sector & Jan/feb 1999 & $0,25-0,93$ & 0,5 & 63 & -45 & 95 & 47 & $1353 \mathrm{~L}$ & 3 Leblanc et al, 2002 & 34 \\
\hline Polar & Southern Ocean & SUBANT & Pacific & Summer 1998 & $0,6-2,58$ & 1,1 & 142 & -47 & 95 & 102 & $2955 \mathrm{C}-\mathrm{C} \cdot \mathrm{C} \cdot \mathrm{C}$ & Queguiner et al, 2001 & 30 \\
\hline Polar & Southern Ocean & SUBANT & East of New Zealand & & & 2,0 & -175 & -54 & 95 & 190 & 55231 & Nelson and Gordon, 1982 & 29 \\
\hline Polar & Southern Ocean & SUBANT & Indian sector & & & 1,7 & 146 & -48 & 95 & 162 & & Beucher et al, 2004 & 25 \\
\hline Polar & Pacific & BERS & Bering Sea outer & May/July 1979 - 1981 & $1,8-25$ & 10,1 & -167 & 55,5 & 95 & 962 & 3741 & I Banahan and Goering, 1988 & 21 \\
\hline Coastal & Pacific & CAMR & Baja California & & $2,3-1140$ & 89,0 & -114 & 27 & 365 & 32485 & $40931 \mathrm{l}$ & Nelson and Goering, 1978 & 35 \\
\hline Coastal & Pacific & CCAL & Coast. upw Monterey & April 1995 & $13-1140$ & 202,0 & $-122,2$ & 36,8 & 175 & 35262 & 33852 & Brzezinski et al., 1997 & 36 \\
\hline Coastal & Pacific & CCAL & Coast. upw Monterey & April 1992 & $22-40$ & 32,0 & $-122,2$ & 36,2 & 175 & 5586 & $5363 \mathrm{E}$ & Brzezinski et al., 1997 & 36 \\
\hline Coastal & Pacific & CCAL & Costa Rica Dome & July 2011 & $0,11-5,57$ & 1,4 & -122 & 33 & 175 & 251 & & Krause et al., 2015 & 37 \\
\hline Coastal & Pacific & CCAL & Santa Barbara & 1996-1997 & 2,4-57,3 & 34,2 & -120 & 34 & 175 & 5970 & $5731 \mathrm{~s}$ & Shipe and Brzezinski, 2001 & 38 \\
\hline Coastal & Pacific & CHIL & Peru Chile upw -BIOSOPE & Oct/Nov 2004 & $42-52$ & 47,0 & -72 & -35 & 190 & 8950 & $23361 \mathrm{~L}$ & L Leblanc et al 2018 & 39 \\
\hline Coastal & Pacific & CHIL & & March/May 1977 & $0,1-4,04$ & 1,2 & -78 & -13 & 190 & 226 & & Nelson 1981 & 40 \\
\hline Coastal & Atlantic & CNRY & NW Africa upw & May 1974 & $14-40$ & 23,0 & $-17,5$ & 21,5 & 222 & 5106 & $4085 \mathrm{I}$ & Nelson and Goering, 1977 & 41 \\
\hline Westerlies & Mediterranean & MEDI & Mediterranean (SOFI) & Dec -Jan 1997/98 & 0,80 & 0,8 & -1 & 36 & 127 & 105 & & S Leblanc et al., 2004 & 42 \\
\hline Westerlies & Mediterranean & MEDI & Mediterranean (SOFI) & 1999/2000 & $0.14-1.4$ & 0,4 & 5 & 43 & 127 & 48 & & Leblanc et al 2003 & 43 \\
\hline Westerlies & Atlantic & NADR & N Atlantic (PAP) & & $0,5-1,3$ & 0,9 & -16 & 48,8 & 127 & 114 & & Ragueneau et al., 1997 & 44 \\
\hline Westerlies & Atlantic & NADR & NE Atlantic & May 2001 & $6-166$ & 35,0 & -15 & 60 & 127 & 4445 & $15558 \mathrm{E}$ & Brown et al. 2003 & 45 \\
\hline Westerlies & Atlantic & NAST (E) & N Atlantic - POMME & March/April/sept 2001 & $0,04-11,2$ & 0,8 & -18 & 42 & 127 & 96 & & 5 Leblanc et al 2005 & 46 \\
\hline Westerlies & Atlantic & NAST (W) & Warm-Core Ring & April/June 1982 & $4,4-11,7$ & 7,1 & -63 & 37 & 127 & 901 & 5228 & Brzezinski and Nelson, 1989 & 47 \\
\hline Westerlies & Atlantic & NAST (W) & Sargasso Sea (BATS) & 1991-1994 & $0,2-1,6$ & 0,7 & -64 & 31,1 & 365 & 240 & $1392 \mathrm{I}$ & Nelson and Brzezinski, 1997 & 48 \\
\hline Westerlies & Atlantic & NAST (W) & Mode-water eddy & April 2007 & $0,13-1,12$ & 0,6 & -64 & 32,5 & 127 & 81 & $471 \mathrm{r}$ & Krause et al., 2010 & 49 \\
\hline Westerlies & Atlantic & $\operatorname{NAST}(\mathrm{W})$ & Sargasso Sea & May/March 1989 & $0,2-1,48$ & 0,6 & -65 & 32 & 127 & 81 & & Brzezinski and Kosman, 1996 & 50 \\
\hline Westerlies & Atlantic & NADR & N. Atlantic (BENGAL) & & & 0,9 & 30 & 46 & 127 & 114 & & Ragueneau et al., 2000 & 51 \\
\hline Trades & Pacific & NPTG & Central North Pacific & August 1995 & $0,5-2,9$ & 1,2 & -155 & 28 & 365 & 453 & $9545 \mathrm{E}$ & Brzezinski et al 1998 & 52 \\
\hline Trades & Pacific & NPTG & HOT-ALOHA & & $0,09-0,49$ & 0,2 & -158 & 22,5 & 365 & 63 & $1329 \mathrm{E}$ & Brzezinski et al., 2011 & 53 \\
\hline Trades & Pacific & NPTG & Subtropical front & summer bloom & $0,10-1,74$ & 0,6 & -150 & 27 & 365 & 219 & $4619 \mathrm{r}$ & Krause et al., 2013 & 54 \\
\hline Trades & Pacific & PEQD & Eq. upwelling & nov-96 & 2,50 & 2,5 & -180 & 0 & 365 & 913 & $9435 \mathrm{~L}$ & Leynaert et al., 2001 & 55 \\
\hline Trades & Pacific & PEQD & Eq. upwelling & nov-96 & $0,1-0,65$ & 0,4 & -180 & 5 & 365 & 146 & $1510 \mathrm{~L}$ & Leynaert et al., 2001 & 55 \\
\hline Trades & Pacific & PEQD & Eq. upwelling & nov-96 & $0,1-0,65$ & 0,4 & -180 & -5 & 365 & 146 & $1510 \mathrm{~L}-2>2>$ & Leynaert et al., 2001 & 55 \\
\hline Trades & Pacific & PEQD & Eastern equa. Upw. & 2004 & $0,6-2,59$ & 1,6 & -110 & -1 & 365 & 584 & $6039 \mathrm{r}$ & Krause et al., 2011 & 56 \\
\hline Trades & Pacific & PEQD & Eastern equa. Upw. & 2005 & $0,3-2,49$ & 1,3 & -125 & 0 & 365 & 475 & $4906 \mathrm{~K}$ & Krause et al., 2011 & 56 \\
\hline Westerlies & Pacific & PSAG & N Pacific (OSP) & & & 5,1 & -145 & 50 & 111 & 566 & $1812 \mathrm{~V}-\mathrm{r} \cdot \mathrm{e}$ & Wong and Matear, 1999 & 57 \\
\hline Polar & Atlantic & SARC & Svalbard & May 2016 & $0,27-1,46$ & 0,8 & 25 & 77 & 127 & 102 & $237 \mathrm{r}$ & Krause et al 2018 & 58 \\
\hline Westerlies & Pacific & SPSG & SE Gyre BIOSOPE & Oct/Nov 2004 & $0,04-0,2$ & 0,1 & -90 & -31 & 127 & 15 & & 3 Leblanc et al 2018 & 39 \\
\hline Westerlies & Pacific & SPSG & HNLC-BIOSOPE & Oct/Nov 2004 & $0,8-5,6$ & 3,6 & -138 & -8 & 127 & 457 & $17043 \mathrm{~L}$ & L Leblanc et al 2018 & 39 \\
\hline Trades & Pacific & WARM & Wequat. oligotrophic & oct-94 & $0,8-2,1$ & 1,4 & -168 & 0 & 365 & 511 & $8575 \mathrm{E}-2>25$ & B Blain et al., 1997 & 59 \\
\hline Trades & Pacific & WARM & W equat. oligotrophic & oct-94 & 3,90 & 3,9 & -160 & 0 & 365 & 1424 & $23886 \mathrm{E}$ & Blain et al., 1997 & 59 \\
\hline Coastal & Atlantic & NECS & Bay of Brest & 2001 & & 2,5 & $-4,6$ & 48,3 & 365 & 900 & 1224 & Del amo et al & 60 \\
\hline Westerlies & Atlantic & NAL & АMT & April- May & & 0,26 & $-16,78$ & 47,45 & 127 & 32 & $113 \mathrm{~F}$ & Poulton et al, 2006 & 61 \\
\hline Westerlies & Atlantic & NASE & АMT & April- May 2004 & & 0,43 & $-20,16$ & 38,5 & 127 & 54 & $241 \mathrm{~F}$ & Poulton et al, 2006 & 61 \\
\hline Westerlies & Atlantic & NASW & АMT & April- May 2004 & & 0,15 & $-36,4$ & 29,2 & 127 & 19 & $110 \mathrm{P}$ & Poulton et al, 2006 & 61 \\
\hline Trades & Atlantic & NATR & АMT & April- May 2004 & & 0,14 & $-33,4$ & 22,2 & 365 & 51 & & Poulton et al, 2006 & 61 \\
\hline Trades & Atlantic & SATL & AMT & April- May 2004 & & 0,31 & $-30,37$ & $-27,48$ & 190 & 60 & $1058 \mathrm{r}$ & tal, 2006 & 61 \\
\hline & Atlantic & WTRA & AMT & April- May 2004 & & 0,58 & $-27,06$ & 6,1 & 365 & 212 & 1135 & $\mathrm{tal}, 2006$ & 61 \\
\hline Westerlies & Atlantic & NADR & Celtic Sea & nov-14 & & 1,00 & $-8,83$ & 48,75 & 127 & 127 & & Poulton et al, 2019 & 62 \\
\hline
\end{tabular}

272 Note that « $\mathrm{d} »$, duration of the productive period in days, was extrapolated from the bloom phenology for each province (calculated as the 273 number of day where the chloro concentration is greater than the average concentration between the maximun and the minimum values). 


\section{Average per province}

\begin{tabular}{|c|c|c|c|c|c|c|}
\hline Biome & Province & $\begin{array}{l}\text { Surface } \\
10^{6} \mathrm{~km}^{2}\end{array}$ & $\begin{array}{c}\text { Average } \\
\text { mmol-Si m }^{-2} \text { day }^{-1}\end{array}$ & $\begin{array}{c}\text { Prod. duration } \\
\text { day }\end{array}$ & $\begin{array}{c}\text { Annual PBSi } \\
\text { mmol-Si m}^{-2} a^{-1} \\
\end{array}$ & $\begin{array}{c}\text { Annual PBSi } \\
10^{9} \mathrm{~mol}^{-S_{i} a^{-1}}\end{array}$ \\
\hline Coastal upw & CNRY & 0,8 & 23,0 & 190 & 4380 & 3504 \\
\hline Coastal & NECS & 1,4 & 2,5 & 159 & 391 & 532 \\
\hline Polar & SARC & 2,3 & 0,8 & 127 & 102 & 237 \\
\hline Westerlies & NADR & 3,5 & 9,3 & 127 & 1176 & 4116 \\
\hline Westerlies & NAST (E) & 0,4 & 0,6 & 127 & 75 & 28 \\
\hline Westerlies & NAST (W) & 5,8 & 1,8 & 127 & 233 & 1353 \\
\hline Westerlies & MEDI & 3,1 & 0,6 & 127 & 77 & 237 \\
\hline Coastal & ALSK & 0,6 & 20,9 & 159 & 3317 & 1957 \\
\hline Coastal upw & CAMR & 1,3 & 89,0 & 365 & 32485 & 40931 \\
\hline Coastal upw & CCAL & 1,0 & 67,4 & 175 & 11767 & 11297 \\
\hline Coastal upw & CHIL & 2,6 & 24,1 & 190 & 4588 & 11975 \\
\hline Polar & BERS & 3,9 & 10,1 & 95 & 962 & 3741 \\
\hline Trades & NPTG & 21,1 & 0,7 & 365 & 245 & 5164 \\
\hline Trades & PEQD & 10,3 & 1,2 & 365 & 453 & 4680 \\
\hline Trades & WARM & 16,8 & 2,7 & 365 & 967 & 16230 \\
\hline Westerlies & PSAE & 3,2 & 5,1 & 111 & 567 & 1813 \\
\hline Westerlies & SPSG & 37,3 & 1,9 & 127 & 236 & 8806 \\
\hline Westerlies & SUBANT & 29,0 & 1,3 & 95 & 125 & 3631 \\
\hline Polar & PFZ & 9,0 & 15,2 & 130 & 1968 & 17715 \\
\hline Polar & POOZ & 12,0 & 10,7 & 114 & 1213 & 14553 \\
\hline Polar & SIZ & 21,0 & 8,6 & 114 & 980 & 20574 \\
\hline Westerlies & NASW & 5,8 & 0,2 & 127 & 19 & 110 \\
\hline Trades & NATR & 8,3 & 0,1 & 365 & 51 & 423 \\
\hline Trades & SATL & 17,8 & 0,3 & 190 & 60 & 1058 \\
\hline Trades & WTRA & 5,4 & 0,6 & 365 & 212 & 1135 \\
\hline Polar & CCSZ & 2,0 & 33,7 & 79 & 2676,0 & 5352,0 \\
\hline
\end{tabular}

\section{Average per Ocean Basin}

\begin{tabular}{|c|c|c|c|c|c|c|}
\hline Ocean & $\begin{array}{l}\text { Surface } \\
10^{6} \mathrm{~km}^{2}\end{array}$ & portion in AO & $\begin{array}{c}\text { Surface } \\
\text { considered* }\end{array}$ & $\begin{array}{l}\text { Annual PBSi } \\
\mathrm{mmol} \mathrm{m}^{-2} \mathrm{an}^{-1}\end{array}$ & $\begin{array}{l}\text { Annual PBSi } \\
10^{9} \mathrm{~mol} \mathrm{an}^{-1}\end{array}$ & \% PBSi Total \\
\hline Atlantic & 106 & 20 & 86 & 250 & 21501 & 8,6 \\
\hline Pacific & 166 & 32 & 134 & 1088 & 145736 & 58,6 \\
\hline Southern Ocean* & & & 73 & 586 & 42760 & 17,2 \\
\hline Arctic & 14 & & 14 & 102 & 1422 & 0,6 \\
\hline Indien & 75 & 21 & & & 37188 & 15,0 \\
\hline Sub Total & 361 & & 307 & & 211419 & \\
\hline & & & \multicolumn{2}{|l|}{ Annual World PBSi } & 248607 & \\
\hline
\end{tabular}

\section{Average per domain (Longhurst \& Tréguer and Jacques for the OA)}

\begin{tabular}{|c|c|c|c|c|c|c|}
\hline Domain & Biome & $\begin{array}{l}\text { Surface } \\
10^{6} \mathrm{~km}^{2}\end{array}$ & $\begin{array}{c}\text { Annual PBSi } \\
\mathrm{mmol} \mathrm{m}^{-2} \mathrm{an}^{-1}\end{array}$ & $\begin{array}{l}\text { Annual PBSi } \\
10^{9} \mathrm{~mol} \mathrm{an}^{-1}\end{array}$ & $\begin{array}{l}\text { Annual PBSi } \\
10^{9} \mathrm{~mol} \mathrm{an}^{-1}\end{array}$ & \% PBSi Total \\
\hline \multirow{2}{*}{ Coastal } & Coastal & 29 & 1276 & 37017 & \multirow{2}{*}{138036} & 13,0 \\
\hline & upw & 8 & 12026 & 101019 & & 35,5 \\
\hline Polar & Polar ${ }^{*}$ & 54 & 1238 & 66827 & 66827 & 23,5 \\
\hline \multirow{2}{*}{ Open Ocean } & Westerlies $^{*}$ & 130 & 228 & 29647 & \multirow{2}{*}{80063} & 10,4 \\
\hline & Trades & 140 & 360 & 50416 & & 17,7 \\
\hline
\end{tabular}

*Surface considered: this is the ocean surface minus the Antarctic ocean

*Polar: surface includes the Antarctic Ocean (from the polar front poleward, i.e. $4410^{6} \mathrm{~km}^{2}$ ) + arctic zones as defined by Longhurst *Westerlies: includes the subantarctic zone

*Southern Ocean: includes the Antarctic Ocean and the subantarctic zone (i.e. respectively $4410^{6} \mathrm{~km}^{2}+2910^{6} \mathrm{~km}^{2}$ )

278 S21. Banahan, S. \& Goering, J. J. The production of biogenic silica and its accumulation on the southeastern

Bering Sea shelf. Cont. Shelf Res. 5, 199-213 (1986). 
S22. Nelson, D. M., Ahern, J. A. \& Herlihy, L. J. Cycling of biogenic silica within the upper water column of the Ross Sea. Mar. Chem. 35, 461-476 (1991).

S23. Nelson, D. M. \& Smith Jr, W. O. Phytoplankton bloom dynamics of the western Ross Sea ice edge. 11.Mesoscale cycling of nitrogen and silicon. Deep Sea Res. 33, 1389-1412 (1986).

S24. Caubert, T. Production de silice biogène dans l'océan Austral: détermination par spectrométrie de masse. PhD, Université de Bretagne Occidentale, Brest, 190pp. (1998).

S25. Beucher, C., Tréguer, P., Corvaisier, R., Hapette, A. \& Elskens, M. Production and dissolution of biosilica, and changing microphytoplankton dominance in the Bay of Brest (France). Mar. Ecol. Prog. Ser. 267, 57-69 (2004).

S26. Quéguiner, B. \& Brzezinski, M. A. Biogenic silica production rates and particulate organic matter distribution in the Atlantic sector of the Southern Ocean during austral spring 1992. Deep Sea Res. II: Topical Studies in Oceanogr. 49, 1765-1786 (2002).

S27. Quéguiner, B., Tréguer, P. \& Nelson, D. M. The production of biogenic silica in the Weddell and Scotia Seas. Mar. Chem. 35, 449-459 (1991).

S28. Brzezinski, M. A., Nelson, D. M., Franck, V. M. \& Sigmon, D. E. Silicon dynamics within an intense open-ocean diatom bloom in the Pacific sector of the Southern Ocean. Deep Sea Res. Part II: Topical Studies in Oceanography 48, 3997-4018 (2001).

S29. Nelson, D. M. \& Gordon, L. I. Production and pelagic dissolution of biogenic silica in the Southern Ocean. Geochim. Cosmochim. Acta 46, 491-501 (1982).

S30. Quéguiner, B. Biogenic silica production in the Australian sector of the Subantarctic Zone of the Southern Ocean in late summer 1998. J. Geophys. Res. 106, 31627-31636 (2001).

S31. Closset, I. et al. Seasonal evolution of net and regenerated silica production around a natural Fe-fertilized area in the Southern Ocean estimated with Si isotopic approaches. Biogeosciences 11, 5827-5846 (2014).

S32. Leynaert, A., Nelson, D., Quéguiner, B. \& Tréguer, P. The silica cycle in the Antarctic Ocean: is the Weddell Sea atypical? Mar. Ecol. Prog. Ser. 96, 1-15 (1993).

S33. Tréguer, P. et al. Production of biogenic silica in the Weddell-Scotia Seas measured with 32Si. Limnol. Oceanogr. 36, 1217-1227 (1991).

S34. Leblanc, K. et al. Particulate biogenic silica and carbon production rates and particulate matter distribution in the Indian sector of the Subantarctic Ocean. Deep Sea Res. Part II: Topical Studies in Oceanogr. 49, 3189-3206 (2002).

S35. Nelson, D. M. \& Goering, J. J. Assimilation of silicic acid by phytoplankton in the Baja California and northwest Africa upwelling systems 1: Silicic acid uptake. Limnol. Oceanogr. 23, 508-517 (1978).

S36. Brzezinski, M. A. \& Phillips, D. R. Evaluation of ${ }^{32} \mathrm{Si}$ as a tracer for measuring silica production rates in marine waters. Limnol. Oceanogr. 42, 856-865 (1997).

S37. Krause, J. W. et al. Variability in diatom contributions to biomass, organic matter production and export across a frontal gradient in the California Current Ecosystem. J. Geophys. Res. Oceans 120, 1032-1047 (2015).

S38. Shipe, R. F. \& Brzezinski, M. A. A time series study of silica production and flux in an eastern boundary region: Santa Barbara Basin, California. Glob. Biogeochem. Cycles 15, 517-531 (2001).

S39. Leblanc, K. et al. Silicon cycle in the Tropical South Pacific: evidence for an active pico-sized siliceous 
plankton. Biogeosciences (2018).doi:10.5194/bg-2018-149.

S40. Nelson, D. M., Goering, J. J. \& Boisseau, D. W. Consumption and regeneration of silicic acid in three coastal upwelling systems. Coast. Est. Sci. 1, 242-256 (1981).

S41. Nelson, D. M. \& Goering, J. J. Near-surface silica dissolution in the upwelling region off northwest Africa. Deep Sea Research 24, 65-73 (1977).

S42. Leblanc, K. Siliceous phytoplankton production and export related to trans-frontal dynamics of the Almeria-Oran frontal system (western Mediterranean Sea) during winter. J. Geophys. Res. 109, C07010 (2004).

S43. Leblanc, K., Quéguiner, B., Garcia, N., Rimmelin, P. \& Raimbault, P. Silicon cycle in the NW Mediterranean Sea: seasonal study of a coastal oligotrophic site. Oceanol. Acta 26, 339-355 (2003).

S44. Ragueneau, O. et al. OPALEO (OPAL as PALEO-productivity proxy), Synthesis and perspectives, in Final Report From the First 2 International Workshop (Brest 96, Corvallis 97), edited by O. Ragueneau, A. Leynaert, and P. Tréguer, Brest, France (1997).

S45. Brown, L., Sanders, R., Savidge, G. \& Lucas, C. H. The uptake of silica during the spring bloom in the Northeast Atlantic Ocean. Limnol. Oceanogr. 48, 1831-1845 (2003).

S46. Leblanc, K. et al. A seasonal study of diatom dynamics in the North Atlantic during the POMME experiment (2001): Evidence for Si limitation of the spring bloom. J. Geophys. Res. 110, C07S14 (2005).

S47. Brzezinski, M. A. \& Nelson, D. M. Seasonal changes in the silicon cycle within a Gulf Stream warmcore ring. Deep Sea Res. Part A. Oceanogr. Res. Papers 36, 1009-1030 (1989).

S48. Nelson, D. M. \& Brzezinski, M. A. Diatom growth and productivity in an oligo-trophic midocean gyre: A 3-yr record from the Sargasso Sea near Bermuda. Limnol. Oceanogr. 42, 473-486 (1997).

S49. Krause, J. W., Nelson, D. M. \& Lomas, M. W. Production, dissolution, accumulation, and potential export of biogenic silica in a Sargasso Sea mode-water eddy. Limnol. Oceanogr. 55, 11 (2010).

S50. Brzezinski, M. \& Kosman, C. Silica production in the Sargasso Sea during spring 1989. Mar. Ecol. Prog. Ser. 142, 39-45 (1996).

S51. Ragueneau, O. et al. A review of the Si cycle in the modern ocean: recent progress and missing gaps in the application of biogenic opal as a paleoproductivity proxy. Glob. Planet. Change 26, 317-365 (2000).

S52. Brzezinski, M., Villareal, T. \& Lipschultz, F. Silica production and the contribution of diatoms to new and primary production in the central North Pacific. Mar. Ecol. Prog. Ser. 167, 89-104 (1998).

S53. Brzezinski, M. A. et al. The annual silica cycle of the North Pacific subtropical gyre. Deep Sea Res. Part I: Oceanogr. Res. Papers 58, 988-1001 (2011).

S54. Krause, J. W., Brzezinski, M. A., Villareal, T. A. \& Wilson, C. Biogenic silica cycling during summer phytoplankton blooms in the North Pacific subtropical gyre. Deep Sea Res. Part I: Oceanogr. Research Papers 71, 49-60 (2013).

S55. Leynaert, A., Tréguer, P., Lancelot, C. \& Rodier, M. Silicon limitation of biogenic silica production in the Equatorial Pacific. Deep Sea Res. Part I 48, 639-660 (2001).

S56. Krause, J. W., Nelson, D. M. \& Brzezinski, M. A. Biogenic silica production and the diatom contribution to primary production and nitrate uptake in the eastern equatorial Pacific Ocean. Deep Sea Res. Part II: Topical Studies in Oceanogr. 58, 434-448 (2011).

S57. Wong, C. S. \& Matear, R. J. Sporadic silicate limitation of phytoplankton productivity in the subarctic 
S58. Krause, J.W. et al. Biogenic silica production and diatom dynamics in the Svalbard region during spring. Biogeosciences 15, 6503-6517 (2018).

S59. Blain, S. et al. Biomass, growth rates and limitation of Equatorial Pacific diatoms. Deep Sea Res. Part I: Oceanogr. Res. Papers 44, 1255-1275 (1997).

365

S60. Del Amo, Y., Queguiner, B., Treguer, P., Breton, H. \& Lampert, L. Impacts of high-nitrate freshwater inputs on macrotidal ecosystems. 11. Specific role of the silicic acid pump in the year-round dominance of diatoms in the Bay of Brest (France). Mar. Ecol. Progr. Ser. 161, 225-237 (1997).

S61. Poulton A.J. et al. (2006) Phytoplankton mineralization in the tropical and subtropical Atlantic Ocean. Glob. Biogeochem. Cycles 20, GB4002 (2006).

S62. Poulton A.J. et al. (2019) Dissolution dominates silica cycling in a shelf sea autumn bloom. Geophys. Res. Lett. 46, 6765 - 6774 (2019). 